\title{
Prioritizing conservation of tropical dry forests in the Pacific
}

\author{
Thomas W. Gillespie, Kristin O’Neill, Gunnar Keppel, Stephanie Pau \\ Jean - Yves Meyer, Jonathan P. Price and Tanguy Jaffré
}

\begin{abstract}
To identify forests of high priority for conservation in tropical dry forests of New Caledonia, Fiji, the Marquesas and Hawaii, we examined patterns of woody plant species richness (total, native and endemic) and threatened species (IUCN categorization and density) at the stand level, using Gentry's transect method. There were associations between total, native and endemic plant species richness in all four Pacific dry forest regions but we found no significant association with the presence or density of species listed on the IUCN Red List. Dry forests in New Caledonia and Hawaii merit the highest conservation priority in the Pacific, based on level of endemism and number of threatened species. The study sites that merit high conservation priority are Metzdorf, Nekoro and Pindai, in New Caledonia, Kokee and Kaupulehu, in Hawaii, and Vatia, in Fiji. New Caledonia and Fiji have a small dry forest extent and protected area extent compared with other dry forests in biodiversity hotspots. Although we identified priority areas for dry forest conservation, more comparative plot data, presence/absence data in fragments and regional geographical data are needed to adequately manage and protect dry forests in the Pacific.
\end{abstract}

Keywords Biodiversity hotspots, dry forest, geographical information system, IUCN Red List, Pacific, species richness

This paper contains supplementary material that can be found online at http://journals.cambridge.org

THOMAS W. GiLLESPIE (Corresponding author) and Kristin O'Neill Department of Geography, University of California Los Angeles, 1255 Bunche Hall, PO Box 951524, Los Angeles, California 90095-1524, USA. E-mail tg@geog.ucla.edu

GunNar Keppel School of Natural and Built Environments and Barbara Hardy Institute, University of South Australia, Adelaide, Australia

StePHANIE Pau Department of Geography, Florida State University, Tallahassee, USA

Jean-Yves Meyer Délégation à la Recherche, Gouvernement de Polynésie Française, Papeete, Tahiti

Jonathan P. Price Department of Geography and Environmental Studies, University of Hawaii, Hilo, USA

TANGUY JAFFRÉ Laboratoire de Botanique et d'Ecologie Végétale Appliquées, Institut de Recherche pour le Développement, Nouvelle-Calédonie

Received 21 June 2012. Revision requested 18 October 2012.

Accepted 20 February 2013. First published online 17 February 2014.

\section{Introduction}

Tropical dry forest, also known as seasonally dry tropical 1 forest, can be loosely defined as forest in frost-free regions with 500-2,000 mm of precipitation annually and a pronounced dry season of 4-7 months (Walter, 1971; Murphy \& Lugo, 1986; Miles et al., 2006). Isolated oceanic islands in the Pacific contain tropical dry forest and a number of endemic plant species with small geographical ranges (Mueller-Dombois \& Fosberg, 1998). There have been high levels of deforestation and degradation of tropical dry forests on these islands, which have a long history of anthropogenic disturbance (Rolett \& Diamond, 2004). New Caledonia, Fiji, the Marquesas and Hawaii have been deforested for agriculture, and forests have been degraded by fire, grazing and invasion of non-native species of plants and animals (Cuddihy \& Stone, 1990; Cabin et al., 2002; Meyer, 2004). According to the definition of Fisher \& Lindenmayer (2007) the majority of remaining native dry forest fragments in the Pacific can be considered relictual because they have been reduced to $<10 \%$ of their original cover, and almost all remaining fragments are $<100$ ha. Thus, they provide a good opportunity to examine methods used to identify patterns of species richness in fragmented systems and compare the conservation status of these forests with other regions (Gordon et al., 2003).

There is a growing interest in identifying tropical forests and forest fragments in regions that have a high conservation priority at a global spatial scale (Miles et al., 2006; Schmitt et al., 2009). However, there are few comparative data on the relationship between various metrics and stand species richness across different geographical regions (Gordon et al., 2003) and there is an ongoing debate about the importance of species richness as a metric for conservation planning. Levels of species richness in stands of tropical forests have been identified as an important metric for studying the conservation value of forests and nature reserves (Arroyo-Rodriguez et al., 2008). However, some researchers maintain that the number of range-restricted or endemic species and presence or densities of threatened species are equally important metrics for prioritizing conservation areas (Kerr, 1997; Chapman et al., 2009).

Biodiversity hotspots are regions that contain exceptional concentrations of endemic species whose habitat is threatened by human activity (Myers et al., 2000; Myers, 2003; Conservation International, 2009). The resources 


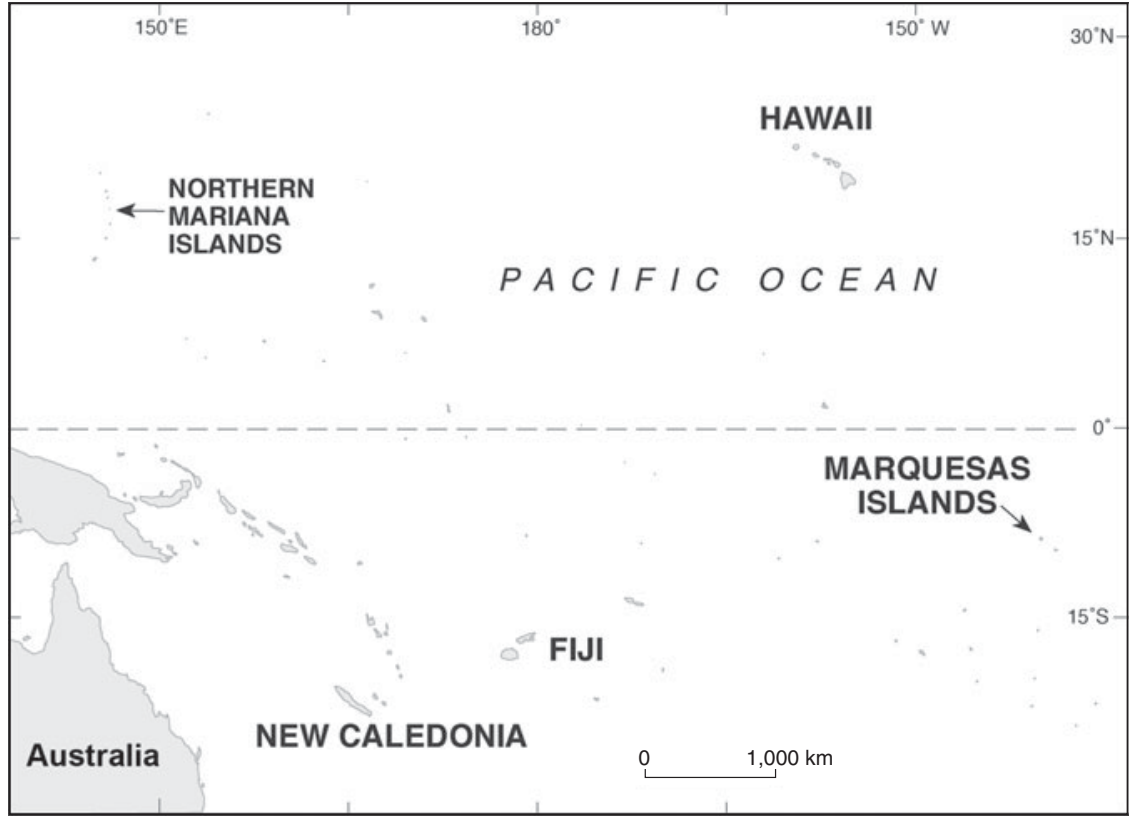

FIG. 1 Pacific archipelagos with tropical dry forests. available for conservation in biodiversity hotspots are inadequate to protect all species and therefore it would be more effective to concentrate conservation efforts in areas with the highest levels of biodiversity and the highest numbers of threatened species. Gentry transects provide a standard and repeatable method that can be used to compare levels of species richness and risk of extinction (Gentry, 1995; Phillips \& Miller, 2002), and geographical information system (GIS) polygons of tropical dry forest regions and satellite imagery (MODIS $500 \mathrm{~m}$ resolution) have been used to identify the extent of dry forests at a global spatial scale (Miles et al., 2006; Schmitt et al., 2009; PortilloQuintero \& Sánchez-Azofeifa, 2010), although there are few comparative plot or forest extent data for biodiversity hotspots in the Pacific (Miles et al., 2006; Pau et al., 2009; Pennington et al., 2009; Schmitt et al., 2009). There have been significant advances in the spatial resolution of GIS and remote-sensing data, which can be used to assess the extent and conservation status of dry forests in biodiversity hotspots. WWF's ecoregions approach has provided comparative data on large units of land and water containing geographically distinct assemblages of species, natural communities and environmental conditions, at a global spatial scale (Olson et al., 2001), and there have been advances in the spatial resolution of land-cover classifications such as the European Space Agency's GlobCover dataset, which provides 22 land-cover classes (six terrestrial forest types) at a $300 \times 300 \mathrm{~m}$ pixel resolution (ESA, 2010).

Our research had three primary objectives. Firstly, we examined the relationship between total species richness, native species richness, number of endemic species and number of threatened woody plant species (trees, shrubs, lianas) at the stand level. In particular, we tested the hypothesis that total species richness at the stand level is positively associated with native species richness, endemic species richness, and presence and density of threatened species across all four regions (New Caledonia, Fiji, Hawaii and the Marquesas). Secondly, we assessed the conservation priorities of tropical dry forest sites in the Pacific based on the presence and density of threatened species and levels of endemism. Thirdly, we calculated the extent of tropical dry forests and protected areas in the New Caledonia and Polynesia-Micronesia biodiversity hotspots to assess the conservation priorities in the region.

\section{Study area}

This research was undertaken on four oceanic island archipelagoes (New Caledonia, Fiji, the Marquesas and Hawaii) within the New Caledonia and PolynesiaMicronesia biodiversity hotspots (Myers et al., 2000; Fig. 1). Study sites were selected based on Landsat ETM+ data from 2005, WorldClim climate data extrapolated from climate stations (WorldClim, 2009), and Shuttle Radar Topography Mission data, to identify the best-preserved forest fragments in regions with 500-2,000 $\mathrm{mm}$ of annual precipitation and a pronounced dry season (Hijmans et al., 2005). We conducted field visits to potential sites to ensure that they hosted native tree species. We surveyed a total of 37 dry forest sites (Fig. 2). Seven sites were surveyed on the western side of Grand Terre, New Caledonia. Nine sites were surveyed in western Fiji: Yasawa group (4), Mamanuca group (1), Viti Levu (2) and islands near Viti Levu and Vanua Levu (2). Six sites were surveyed on the two largest islands in the Marquesas: Nuku Hiva (3) and 

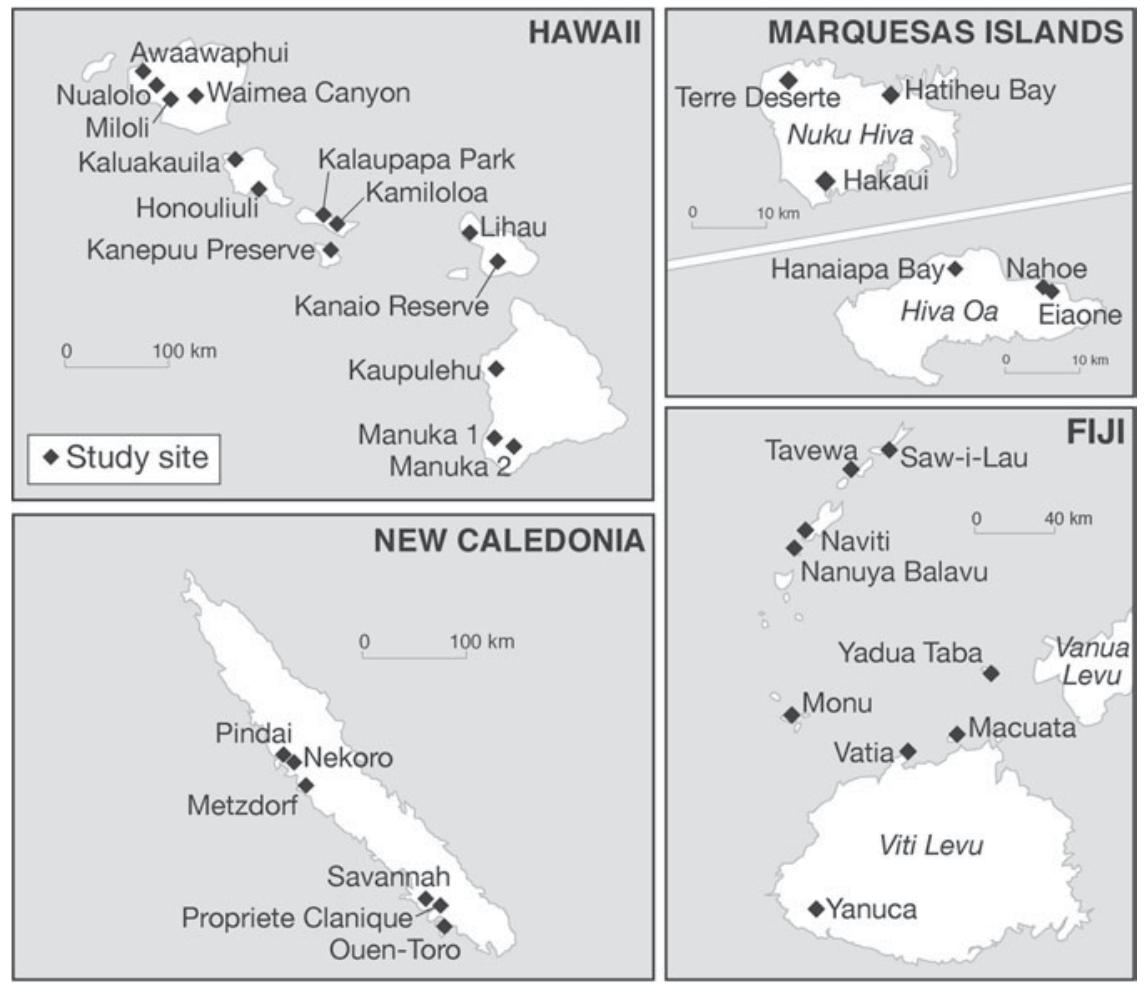

FIG. 2 Locations of our study sites in tropical dry forests on the Pacific islands of Hawaii, New Caledonia, the Marquesas and Fiji.
Hiva $\mathrm{Oa}$ (3). Fifteen sites were surveyed on six Hawaiian islands: Kauai (4), Oahu (2), Molokai (1), Lanai (3), Maui (2), and the island of Hawaii (3). Detailed overviews of each region and our study areas are available at Gillespie (2013).

\section{Methods}

Data on species richness, floristic composition and forest structure at each study site were collected following Gentry (1988). Belt transects of $1,000 \mathrm{~m}^{2}$ (o.1 ha) were established at each site. Each survey consisted of 10 transects $(2 \times 50 \mathrm{~m})$, spaced $10 \mathrm{~m}$ apart, in which all plants of diameter at breast height $\geqslant 2.5 \mathrm{~cm}$ rooted in the sample area were recorded (Gentry, 1988). In New Caledonia, Fiji, and Hawaii, plants were identified to species or morphospecies at the local herbaria: Institut de recherche pour le développement (IRD) in Nouméa, New Caledonia; South Pacific Regional Herbarium (SUVA) at the University of the South Pacific in Suva, Fiji; and Bishop Museum in Honolulu, Hawaii (BISH). All species from the Marquesas were identified according to Wagner \& Lorence (2003). At each site species were identified as native, endemic to the regional archipelago or non-native, and threatened species were categorized as Critically Endangered, Endangered or Vulnerable according to the IUCN Red List (IUCN, 2012).

We collected four GIS layers to identify the extent of ecoregion, dry forest and protected forest in Pacific biodiversity hotspots. Ecoregion polygons were acquired from WWF (2009) for dry forest in the New Caledonia and Polynesia-Micronesia biodiversity hotspots (Conservation International, 2009). We acquired the European Space Agency's GlobCover v. 2.1 dataset (ESA, 2010), which contains three terrestrial forest land-cover classifications that correspond to tropical dry forest: (1) $>5 \mathrm{~m}$ tall closed to open $\left(>_{15} \%\right)$ broadleaved evergreen or semi-deciduous forest; (2) closed $(>40 \%)$ broadleaved deciduous forest; (3) open (15-40\%) broadleaved deciduous forest. Protected area polygons were acquired from the World Database on Protected Areas (IUCN/UNEP, 2009). Only terrestrial protected areas in categories I to VI were included (IUCN, 2009).

Species richness data (total richness, native richness and endemic richness) had a normal distribution within each region, based on a one-sample Kolmogorov-Smirnov test, and therefore a Pearson product correlation was used to identify whether total species richness was associated with native richness or endemic richness. The number and density of Red-Listed species did not have a normal distribution, and thus we used a Spearman's rank correlation between total species richness and number and density of threatened species in 0.1 ha plots. We ranked conservation priorities of sites, based on the number and density of Red-Listed species and the number of endemic species in the 0.1 ha plots. Ecoregions within the PolynesiaMicronesia and New Caledonia biodiversity hotspots that contain dry forest were overlain on GlobCover data 
TABLE 1 Number (and percentage) of native, endemic and non-native species, number of Red-Listed species (Critically Endangered, Endangered or Vulnerable), and number of individuals of Red-Listed species of woody plants $\geqslant 2.5 \mathrm{~cm}$ diameter at breast height rooted within Gentry transects at our study sites on the Pacific islands of New Caledonia, Fiji, Marquesas and Hawaii (Fig. 2).

\begin{tabular}{lllrr}
\hline & New Caledonia & Fiji & Marquesas & Hawaii \\
\hline Native species & $45(37 \%)$ & $46(57 \%)$ & $10(59 \%)$ & $7(10 \%)$ \\
Endemic species & $73(59 \%)$ & $25(31 \%)$ & $2(12 \%)$ & $45(67 \%)$ \\
Non-native species & $5(4 \%)$ & $10(12 \%)$ & $5(29 \%)$ & $15(23 \%)$ \\
Red-Listed species & 13 & 1 & 0 & 7 \\
Individuals of Red-Listed species & 72 & 40 & 0 & 123 \\
\hline
\end{tabular}

TABLE 2 Correlations of total species richness with native and endemic species richness (Pearson product correlation) and number and density of Red-Listed species (Spearman's rank correlation) in 0.1 ha plots in tropical dry forest in New Caledonia, Fiji, Marquesas and Hawaii (Fig. 2). Blank cells indicate that no Red-Listed species were encountered in plots.

\begin{tabular}{lllll}
\hline & New Caledonia & Fiji & Marquesas & Hawaii \\
\hline Native species richness & $0.892^{\star *}$ & $0.830^{\star *}$ & $0.920^{\star *}$ & $0.521^{\star}$ \\
Endemic species richness & $0.885^{* *}$ & $0.824^{* *}$ & 0.583 & $0.889^{* * *}$ \\
Number of Red-Listed species & -0.081 & 0.550 & 0.380 \\
Density of Red-Listed species & -0.037 & 0.588 & 0.146 \\
\hline
\end{tabular}

${ }^{\star} \mathrm{P}<0.05 ;{ }^{* *} \mathrm{P}<0.01 ;{ }^{* *} \mathrm{P}<0.001$

to calculate forest extent in each ecoregion. Protected area polygons were then overlain to identify the extent of forest in protected areas.

\section{Results}

A total of 265 species or morphospecies were identified from 8,769 stems at the 37 sites. Forests in New Caledonia and Fiji contained the highest species richness (Table 1), and forests in New Caledonia and Hawaii had the highest number and proportion of endemic and threatened species and the highest number of threatened individuals (Table 1; Supplementary Table 1). The dry forests of Fiji and the Marquesas had a high proportion of native species and a lower number and density of threatened species than New Caledonia and Hawaii.

There were significant positive correlations between total woody plant species richness and native species richness in all four Pacific dry forests (Table 2). Total species richness was significantly correlated with endemic species richness in New Caledonia, Fiji and Hawaii. There were no correlations between total species richness and number of threatened species or density of threatened species in any of the forests.

We ranked the conservation priorities of the tropical dry forest sites (Supplementary Table 1). New Caledonia had the most sites with a high number and density of threatened species and number of endemic species, followed by Hawaii, Fiji and the Marquesas (Supplementary Table 2). In New Caledonia, Metzdorf, Nekoro and Pindai have a high conservation priority, and in the Hawaiian Islands
Kokee (on the island of Kauai) and Kaupulehu (on the island of Hawaii) have a high conservation priority. Vatia, on the island of Viti Levu, has the highest conservation priority in Fiji, although Naviti and Yanuca both had a high number of endemic species. In the Marquesas we did not encounter any threatened species, and Hatiheu and Hakaui, on Nuku Hiva, had the highest levels of endemism.

There are six tropical dry forest ecoregions (WWF, 2009) within the New Caledonia and Polynesia-Micronesia biodiversity hotspots (Table 3). Marquesas tropical dry forest is not recognized as an ecoregion and there are no land-cover data for this forest in the GlobCover dataset. Fijian tropical dry forest had the largest ecoregion extent, followed by Hawaii and New Caledonia tropical dry forest (Table 3). Forest extents within ecoregions were relatively similar for New Caledonia dry forest (18\%), Hawaiian tropical dry forest (15\%) and Fijian tropical dry forest $(8 \%)$. Fiji had the smallest extent of forest in protected areas $(<1 \%)$, followed by New Caledonia $(7 \%)$.

\section{Discussion}

Relationships between species richness, endemism and endangerment

There were correlations between total species richness, native species richness and endemic species richness in fragmented stands of dry forest in the Pacific. However, there were no correlations between total species richness and number or density of Red-Listed species. This suggests 
TABLE 3 Extent of dry forest (from GlobCover; ESA, 2010) and protected forest in ecoregions with tropical dry forest in the New Caledonia and Polynesia-Micronesia biodiversity hotspots. Blank cells indicate that no data are available.

\begin{tabular}{lccc}
\hline Ecoregion & Ecoregion extent $\left(\mathrm{km}^{2}\right)$ & Dry forest extent $\left(\mathrm{km}^{2}\right)$ & Protected forest extent $\left(\mathrm{km}^{2}\right)$ \\
\hline New Caledonia dry forest & 4,753 & 859 & 62 \\
Fiji tropical dry forest & 12,187 & 948 & 7 \\
Marquesas tropical dry forest & & & 276 \\
Hawaii tropical dry forest & 5,419 & 836 & 6 \\
Marianas tropical dry forest & 1,071 & 26 & 0 \\
Yap tropical dry forest & 103 & 41 & 0 \\
\hline
\end{tabular}

that caution should be taken when assessing the conservation priority of fragments on the basis of total species richness within stands (Kerr, 1997; Chapman et al., 2009). For example, if simple measures of species richness were used to prioritize regions in the Pacific, Hawaii would have a low conservation priority. However, 90\% of the 109 species of trees and shrubs in the dry forest of Hawaii are endemic and $45 \%$ are included on the IUCN Red List (Pau et al., 2009). Thus, studies of species richness patterns should also provide data on endemism and risk of extinction to accurately assess conservation priorities.

Gentry's transect method appears to be appropriate for quantifying patterns of species richness and forest structure in regions where few comparative field data exist. Applying this method, $48 \%$ of known dry forest trees and shrubs of Hawaii were encountered at 15 sites that covered a total of 1.5 ha (Pau et al., 2009) and 29\% of all known dry forest woody plants in New Caledonia were encountered at six sites that covered a total of 0.6 ha (Jaffré et al., 1993). However, only $16 \%$ of the 49 Red-Listed dry forest species were encountered in Hawaii and $11 \%$ of 117 Red-Listed dry forest species were encountered in New Caledonia (Jaffré et al., 1993; Pau et al., 2009). This suggests that rare species may be missed and that extensive presence/absence data for remaining forest fragments are still needed.

\section{Conservation assessment of tropical dry forests in the Pacific}

Based on the number of threatened species and levels of endemism the highest-priority sites for dry forest conservation within the Pacific are in New Caledonia and Hawaii. The most extensive surveys of species in forest fragments have been carried out in New Caledonia, with comparative presence data for woody species available for $>71$ sites (Jaffré et al., 2008). Gentry transects have been used to quantify the regeneration status of stands and threatened species, based on tree size class (Hequet \& Rigault, 2007). New Caledonia also has high levels of microendemism; i.e. subspecies that have evolved in select dry forest locations (Jaffré et al., 2008). These morphological variations are not as pronounced in other dry forest regions in the Pacific.
Presence/absence data are available for islands and the dry forest region of Hawaii (Wagner et al., 1999; Pau et al., 2009) but there are few publicly available data on the distribution of native or threatened species for the dry forest region. For other dry forests in the USA (e.g. in South Florida), presence/absence data are available for all vascular plants for each fragment and standardized plot data are available for a majority of the remaining fragments (Gillespie, 2006; IRC, 2012). These types of occurrence data per fragment or reserve are useful for conservation assessments and monitoring the status of threatened species, especially given that $45 \%$ of dry forest tree species are on the federal endangered species list (Pau et al., 2009).

Dry forest fragments in Fiji occur in a highly modified landscape where frequent fires occur; only a small fraction of these remnants ( $0.7 \%$ of the forest cover) are in protected areas. Although species occurrence data exist for 10 dry forest sites in Fiji (Keppel \& Tuiwawa, 2007) there are no published data for the Yasawa Islands, the driest region in Fiji. There is potential for conservation of forest fragments on these islands but systematic floristic inventories are needed. The IUCN categorization of tropical dry forest species in Fiji is not as complete as in New Caledonia, Hawaii and the Marquesas.

The tropical dry forests of the Marquesas contain some of the lowest levels of native species richness at the stand level because of the relatively small size and young age of the archipelago $\left(1,050 \mathrm{~km}^{2} ; 3.7\right.$ million years old) and its isolation from continental land masses (Wagner \& Lorence, 2003). Decker (1973) highlighted the importance of protecting lowland dry and coastal forests in the Marquesas, which are threatened by overgrazing by feral ungulates (goats, sheep and pigs). Presence/absence data have been recorded for all of the Marquesas islands (Wagner \& Lorence, 2003) but extensive and systematic plant inventories are needed at dry, low elevations on smaller islands not included in our survey. Surveys of the dry lowlands of the Marquesas are also needed to identify the distribution of threatened small trees such as Abutilon sachetianum (Malvaceae; Vulnerable), Chamaesyce sachetiana (Euphorbiaceae; Vulnerable), and Rauvolfia sachetiae (Apocynaceae; Critically Endangered; Lorence \& Butaud, 2011; IUCN, 2012). 


\section{Comparisons with other tropical dry forests in} biodiversity hotspots

We compared the species richness and the number of Red-Listed species categorized as Critically Endangered, Endangered or Vulnerable with other tropical dry forests in biodiversity hotspots in which Gentry's transect method has been employed and where $95 \%$ of the plants encountered were identified to species (Lott et al., 1987; Gentry, 1995; Gillespie et al., 2000; Phillips \& Miller, 2002). We found that species richness at the stand level was lower in the Pacific than in mainland biodiversity hotspots (Supplementary Table 3). Stands of dry forest in New Caledonia, Costa Rica, Tanzania, Thailand and Ecuador contain the highest number of threatened species. However, many trees in Costa Rica and Thailand are on the IUCN Red List because they are threatened by logging but they may yet be very common and have large geographical ranges (Phillips \& Miller, 2002; Gordon et al., 2003). In comparison, RedListed species in New Caledonia are restricted to a small number of sites (Jaffré et al., 2008) and New Caledonian dry forests have a high proportion of Red-Listed species compared to other regions in which Gentry's transect method has been employed. The dry forests of New Caledonia therefore appear to be a high priority for conservation compared to other tropical dry forests in biodiversity hotspots (Jaffré et al., 1998).

Dry forests in the Pacific and Caribbean have a smaller geographical extent and are included in fewer protected areas compared to other dry forests in biodiversity hotspots (Supplementary Table 4). Dry forests in Fiji, Ecuador and New Caledonia have the lowest percentage of protected area of forest. The dry forest cover in the Pacific is estimated to be $<1,000 \mathrm{~km}^{2}$ but the actual extent of native forest may be significantly less. Although ecoregions are useful for identifying the location and distribution of ecosystem types at a global spatial scale and the World Database on Protected Areas is useful for identifying protected areas within ecoregions, there are currently no remote-sensing or GIS data on native forests vs non-native forests (i.e. plantations, forests dominated by non-native tree species) for forest fragments in the Pacific outside of Hawaii, which recently produced a gap analysis or land cover map at a $30 \times 30 \mathrm{~m}$ pixel resolution with non-native forest types (Gillespie et al., 2008). Such data would be useful in the Pacific and other biodiversity hotspots that have a large extent of forest dominated by non-native species.

\section{Implications for conservation}

There are associations between total plant species richness and native and endemic species richness in the dry forests of the four Pacific island groups that we studied but we found no significant association between species richness and the number or density of Red-Listed species. This suggests that although Gentry's transect method provides important comparative data on patterns of species richness, the method does not correlate with the number or density of Red-Listed species. Conservation priorities within regions should be based on occurrence and density data for threatened species in remaining fragments. Globally, the dry forests of Hawaii and New Caledonia merit a high conservation priority because of their high endemism and high numbers of species at risk of extinction. New Caledonia and Fiji have a small extent of dry forest and protected forest compared with other biodiversity hotspots that contain dry forest. Although our study identified high priority areas for conservation of dry forest it also highlighted the limited floristic data available for many Pacific dry forests and the limitations of applying global datasets for the region (i.e. there are no land-cover data for the Marquesas). More comparative plot data, presence/absence data in fragments, and GIS data are required to adequately assess and protect the dry forests of the Pacific.

\section{Acknowledgements}

We thank Christophe Lambert (Environmental Service of the Southern Province) for permission to work in New Caledonia, and Gilles Dagostini and Jerôme Munzinger for help with plant identification at the IRD Herbarium at Nouméa. We thank the National Trust of Fiji and especially local people and village chiefs for permission to do field research in Fiji, and Laura L. Williams from the Division of Fish and Wildlife, who was extremely helpful in the Mariana Islands. We thank the federal and state agencies and the Nature Conservancy of Hawaii for granting us permission to do research in the Hawaiian Islands. We also thank SALVIAS for providing data from Gentry transects, and Cella Carr and two reviewers for their helpful comments and suggestions. This research was funded by the National Geographic Society, National Science Foundation BCS0455052, UCLA Department of Geography and the NASA Earth System Science Fellowship.

\section{References}

Arroyo-Rodriguez, V., Pineda, E., Escobar, F. \& Benitez-Malvido, J. (2008) Value of small patches in the conservation of plant-species diversity in highly fragmented rainforest. Conservation Biology, 23, 729-739.

Cabin, R.J., Weller, S.G., Lorence, D.H., Cordell, S. \& HADWAY, L.J. (2002) Effects of microsite, water, weeding, and direct seeding on the regeneration of native and alien species within a Hawaiian dry forest preserve. Biological Conservation, 104, 181-190.

Chapman, M.G., Underwood, A.J. \& Clarke, K.R. (2009) New indices for ranking conservation sites using 'relative endemism'. Biological Conservation, 142, 3154-3162. 
Conservation International (2009) The Biodiversity Hotspots. Http://www.biodiversityhotspots.org/xp/Hotspots/resources/pages/ maps.aspx [accessed 9 September 2010].

Cuddihy, L.W. \& Stone, C.P. (1990) Alteration of Native Hawaiian Vegetation. Cooperative National Park Resources Studies Unit, University of Hawaii, Honolulu, USA.

Decker, B.G. (1973) Unique dry-island biota under official protection in north western Marquesas islands. Biological Conservation, 5, 66-67.

ESA (European Space Agency) (2010) GlobCover. Http://due.esrin. esa.int/globcover/ [accessed 24 May 2012].

Fisher, J. \& Lindenmayer, D.B. (2007) Landscape modification and habitat fragmentation: a synthesis. Global Ecology and Biogeography, $16,265-280$

Gentry, A.H. (1988) Changes in plant community diversity and floristic composition on environmental and geographical gradients. Annals of the Missouri Botanical Garden, 75, 1-34.

Gentry, A.H. (1995) Diversity and floristic composition of Neotropical dry forests. In Seasonally Dry Tropical Forests (eds S.H. Bullock, H.A. Mooney \& E. Medina), pp. 146-194. Cambridge University Press, Cambridge, UK.

Gillespie, T.W. (2006) Diversity and conservation of tropical dry forests in Florida. In Neotropical Savannas and Seasonally Dry Forests: Plant Diversity, Biogeography and Conservation (eds T. Pennington, G. Lewis \& J. Ratter), pp. 375-386. Taylor \& Francis, Boca Raton, USA.

Gillespie, T.W. (2013) Tropical Dry Forests of the Pacific. Http://www. sscnet.ucla.edu/geog/tdfpacific/ [accessed 13 December 2013].

Gillespie, T.W., Chu, J. \& PaU, S. (2008) Non-native plant invasion of the Hawaiian Islands. Geography Compass, 2, 1241-1265.

Gillespie, T.W., Grijalva, A. \& Farris, C.N. (2000) Diversity, composition, and structure of tropical dry forests in Central America. Plant Ecology, 147, 37-47.

Gordon, J.E., Hawthorne, W.D., Reyes-García, A., Sandoval, G. \& Barrance, A.J. (2004) Assessing landscapes: a case study of tree and shrub diversity in the seasonally dry tropical forests of Oaxaca, Mexico and southern Honduras. Biological Conservation, 117, 429-442.

Hequet, V. \& Rigault, F. (2007) Caractérisation floristique de trois sites de forêt sèche mis en défens en Nouvelle-Calédonie. To en vue d'un suivi écologique. Institut de recherche pour le développement, Marseille, France.

Hijmans, R.J., Cameron, S.E., Parra, J.L., Jones, P.G. \& Jarvis, A. (2005) Very high resolution interpolated climate surfaces for global land areas. International Journal of Climatology, 25, 1965-1978.

IRC (The Institute for Regional Conservation) (2012) Floristic Databases Online. Http://regionalconservation.org/ircs/ DBChoice.asp [accessed 24 May 2012].

IUCN (2009) IUCN Protected Areas Categories System. Http://www. iucn.org/about/work/programmes/gpap_home/gpap_quality/ gpap_pacategories/ [accessed 24 May 2012].

IUCN (2012) The IUCN Red List of Threatened Species. Http://www. iucnredlist.org/ [accessed 24 May 2012].

IUCN/UNEP (2009) World Database on Protected Areas. Http://www.wdpa.org/ [accessed 20 December 2010].

Jaffré, T., Bouchet, P. \& Veillon, J.M. (1998) Threatened plants of New Caledonia: is the system of protected areas adequate? Biodiversity and Conservation, 7, 109-135.

Jaffré, T., Morat, P. \& Veillon, J.M. (1993) Etude floristique et phytogéographique de la forêt sclérophylle de Nouvelle-Calédonie. Bulletin du Muséum National d'Histoire Naturelle, Botanique Series, $15,107-147$.

Jaffré, T., Rigault, F. \& Munzinger, J. (2008) Identification and characterization of floristic groups in dry forests of relicts of a west coast region of New Caledonia. Pacific Conservation Biology, 14, 128-145.

Keppel, G. \& Tuiwawa, M.V. (2007) Dry zone forests of Fiji: species composition, life history traits, and conservation. New Zealand Journal of Botany, 45, 545-563.

KerR, J.T. (1997) Species richness, endemism, and the choice of areas for conservation. Conservation Biology, 11, 1094-1100.

Lorence, D.H. \& Butaud, J.F. (2011) A reassessment of Marquesan Ochrosia and Rauvolfia (Apocynaceae) with two new combinations. PhytoKeys, 4, 95-107.

Lott, E.J., Bullock, S.H. \& Solis-Magallanes, J.A. (1987) Floristic diversity and structure of a tropical deciduous forest of coastal Jalisco. Biotropica, 19, 228-235.

Meyer, J. (2004) Threat of invasive alien plants to native flora and forest vegetation of eastern Polynesia. Pacific Science, 58, 357-375.

Miles, L., Newton, A.C., DeFries, R., Ravilious, C., May, I., BLyth, S. et al. (2006) A global overview of the conservation status of tropical dry forests. Journal of Biogeography, 33, 491-505.

Mueller-Dombois, D. \& FosberG, F.R. (1998) Vegetation of the Tropical Pacific Islands. Springer-Verlag, New York, USA.

Murphy, P.G. \& Lugo, A.E. (1986) Ecology of tropical dry forest. Annual Review of Ecology and Systematics, 17, 67-88.

Myers, N. (2003) Biodiversity hotspots revisited. BioScience, 53, 916-917.

Myers, N., Mittermeier, R.A., Mittermeier, C.G., Da Fonseca, G.A.B. \& Kent, J. (2000) Biodiversity hotspots for conservation priorities. Nature, 403, 853-858.

Olson, D.M., Dinerstein, E., Wikramanayake, E.D., Burgess, N.D., Powell, G.V.N., Underwood, E.C. et al. (2001) Terrestrial ecoregions of the world: a new map of life on Earth. BioScience, 51, 933-938.

Pau, S., Gillespie, T.W. \& Price, J.P. (2009) Natural history, biogeography, and endangerment of Hawaiian dry forest trees. Biodiversity and Conservation, 18, 3167-3182.

Pennington, R.T., Lavin, M. \& Oliveira-Filho, A. (2009) Woody plant diversity, evolution, and ecology in the tropics: perspectives from seasonally dry tropical forests. Annual Review of Ecology, Evolution, and Systematics, 40, 437-457.

Phillips, O. \& Miller, J.S. (2002) Global Patterns of Plant Diversity: Alwyn H. Gentry's Forest Transect Data Set. Missouri Botanical Garden Press, St. Louis, USA.

Portillo-Quintero, C.A. \& Sánchez-Azofeifa, G.A. (2010) Extent and conservation of tropical dry forests in the Americas. Biological Conservation, 143, 144-155.

Rolett, B. \& Diamond, J. (2004) Environmental predictors of pre-European deforestation on Pacific islands. Nature, 431, 443-446.

Schmitt, C.B., Burgess, N.D., Coad, L., Belokurov, A., Besançon, C., Boisrobert, L. et al. (2009) Global analysis of the protection status of the world's forests. Biological Conservation, 142, 2122-2130.

Wagner, W.L., Herbst, D.R. \& Sohmer, S.H. (1999) Manual of the Flowering Plants of Hawaii. Bishop Museum Press, Honolulu, USA.

Wagner, W.L. \& Lorence, D.H. (2003) Flora of the Marquesas Islands. Smithsonian National Museum of Natural History. Institution and National Tropical Botanical Garden. Http://botany. si.edu/pacificislandbiodiversity/marquesasflora/ [accessed 24 May 2012].

Walter, H. (1971) Ecology of Tropical and Subtropical Vegetation. Oliver \& Boyd, Edinburgh, UK.

World Clim (2009) Global Climate Data. Http://www.worldclim.org/ [accessed 24 May 2012]. 
WWF (2009) Terrestrial Ecoregions of the World. Http://worldwildlife. org/publications/terrestrial-ecoregions-of-the-world [accessed 24 May 2012].

\section{Biographical sketches}

Thomas W. Gillespie is a geographer interested in using field data, geographical information systems, and remote-sensing data to predict patterns of species richness and rarity in tropical plants. KRISTIN O'Neill is a biogeographer interested in island ecosystems.
Gunnar KePpel is an ecologist interested in biogeography, community ecology, islands, evolution and population genetics. STEPhanie PaU is a biogeographer interested in understanding the dynamic spatial and temporal responses of ecosystems to climate variability. JEAN-Yves MEYER is a plant ecologist, field botanist and conservation biologist, with expertise in invasive alien species. JONATHAN P. PRICE is a biogeographer interested in understanding spatial patterns in biodiversity, including how these patterns have originated and how human activity has modified them. TANGUY JAFFRÉ is a botanist interested in the biodiversity and conservation of the flora of New Caledonia. 